\title{
Power to the People: An Inverse Role in Nigeria's Politics and Governance
}

\begin{abstract}
An attempt to contextualize the political power structure in Nigeria exposes an orientation and practice that directly negates the democratic norm of power belonging to the people. Today, power belongs entirely to government officials who use it to advance the course of their political and economic interests. The people are thus, subjected to the point and path of complete alienation from the demands and benefits of their democratic citizenship. Given the weakness of the rule of law and institutions of check in Nigeria, established statutes and legislation have not been able to stand tall to relevance in dislodging the hegemony of the ruling elites as is evident in our case study- Imo State. This has since 1999, propped up a telling political effect, which also spirals to the arena of development, and quakes the stability of the state, and the nation at large. The paper examines the current domiciliation of political power, its potential effect on the people, and on service delivery in the country. A case is made for recovery of power for the people and reasserting the law as a balancing force and as means of providing check against breach of constitutionally prescribed political power structure and configuration.
\end{abstract}

Key words: democracy, social contract, patrimonialism, clientelism, sovereignty, popular will

\section{Introduction}

It can be said that in Nigeria, what stands as the representation of the will of the people holds no bearing toward the actual popular will, as represented and exppressed by the Parliament. Indeed, we are confronted by the clarity of a situational contradiction in which, the will of the Executive branch of government becomes an obstruction to that of the popular will. Against the prescriptions of the law, there exist a dangerous and perversive usurpation of political power and sovereignty in Nigeria. In an expressive context, the actual power configuration between the government and the people subverts a part of the fundamental objectives and directive principles of state policy of the Constitution of the Federal Republic of Nigeria 1999 (sec. 14[2a]) as inter alia stated:

"It is hereby, accordingly, declared that- sovereignty belongs to the people of Nigeria from whom government through the Constitution derives all its powers and authority" 
Bearing on the above provision, it is expected that at all times, government will be based on the consent of the governed, but this is no longer the case since politicians force themselves to power and are moved by their ideosyncracies. Voiding the primacy of the people, the reality of a 'hijack' is thus, established. This has altered the preferred power equation, of which, it is possible to draw a template from any of the 36 States of the Federation of Nigeria, to highlight this major fracture.

However, the article examines the out-play of this contradiction in the South Eastern State of Imo; developing an analysis of what becomes of the popular will, with the capitulation of the democratic 'watchdog' institutions. It would also probe the assumption of sovereignty and ownership of the entire apparatus of the state, by the Executive branch that asserts its lordship and absoluteness over the people. Actually, impeding the functions of any of the institutional sites representing the people at the political stage, brings the popular sovereignty concept under threat. This is what obtains in our case study. For this therefore, the paper aligns itself with the views of Obiyo (2007, p.61) that "...the people is deprived of access to a perception of itself, to a mode of self-consciousness without which it seems inappropriate to talk of popular sovereignty". So, the loss of active representation via the 'watchdog' institutions, and of self-consciousness, turned to weakness of the self-will and the conflagration of the welfare rights of the people. The situation indeed, has created a culture of patronage, and of the people having to go 'cap in hand' to be heard, served and have their mandate re-examined. This volumn therefore, exposes an abdication of the norms of the social contract and of checks and balances, citing cases of Executive absolutism, and official policies fashioned to favour government officials as against the general interest.

The paper, therefore, considers the theory of popular sovereignty from the point of view of pluralism, that is, as constituting varied institutional sites and possibilities. This stands against the preponderant influence of a single site, as the works of Rousseau (1968) and Hobbes (1976) propounded (see Obiyo 2007). Indeed, the intent of law for democratic effectiveness and representation, rather than a mere legalistic notion of popular sovereignty, is here, of reference. In this case, a multitude of institutional possibilities is covered, in which in each instance, popular sovereignty assumes the existence of some form of popular consent (Lutz 1980, p.38). The popular will is therefore, represented in terms of the people walking on the path of complete democratic subjectivity, thus, achieving a realisation of itself.

Adherence to 'rule of law' and to the principle of checks and balances, is as necessary as the presence of the people in all the democratic institutions and practices. This is therefore, proposed as an approach to enhance the applicability of popular sovereignty and to secure the primacy of the people in the democratic process. It brings to fore the salience of struggling to reinvent the entire socio-political system and structure, and to reposition a socially and economically dislocated population. The logic of what Stiglitz (2004 p. 273) 
called 'essential pieces of the social contract' here, come as necessary tool to maintain the political balance of a given environment. This, in his view, is in real circumstance, hinged on implicit contracts, understanding the principles and norms, which facilitate the proper functioning of the society. As it is, this is considered as a piece of abandoned principle in Imo State. In practice, the state system and its wealth is in the hands of (and belongs only to) the ruling elites. On the other hand, the people from whom popular sovereignty derives, are under the bondage of frivolities, and subjected to 'praise-singing' the patron-client vogue.

The entire volumn is divided into five separate parts. The first part discusses the compact (the social contract that elicitates authority to the government and sovereignty to the people) and aspects of its pervasion. The second part makes an attempt to situate the problem of leadership, and as well, introduces a notional perception of a shift to 'personal contract', cronyism and clientelism in the management of political power in Imo State, South-East Nigeria. The next section makes analysis of the perceived political dominance by government through patronage and force. This is followed by a study of the social, economic and security implications of a dislocated political system and governance as it affects service delivery. The conclusion outlines the possible ways to go in putting back the people and their welfare at the centre of every political decision in Imo State.

\section{From social contract to neo-patrimonialism}

The popular sovereignty thesis exerted in Rousseau's (1968) social contract theory, aptly defines the place and part of the people, and their privileges in a political community. Kew (2010, p.499) explains that in the contract, the people give their loyalty and support to the government in exchange for the government to provide security and order, and such policies that reflect the broader interests and aspiration of the people (see Rawls 1999, 2001). However, there exist serious contention as regards Rousseau's deemphasis of the Legislature and the Judiciary as balancing force in the pursuit of the popular will. It is worthy of reiteration that government depends on the consent of the governed (see Appadorai 1975, p.28), to which modern democracy is predicated on. Therefore, the Executive depends on the authorization received from the above listed institutional sites of popular representation, to properly function. Following this catch, the people's sovereignty is exercised through the democratic process of providing an 'oversight' control on the process of policy making and implementation.

In the context of the law therefore, the people are paramount, whom the law confers sovereignty, and orders for their security and welfare, as afore iterated. Similarly, to the extent that the law supports the operations of government, 
it is also expected that, "all actions must be judged by their results, by their fruitfulness in pleasure, and this pleasure must find actual expression in the lives and in the experience of definite individuals" (Ibid, p.43). This is the basis of government's mandate. In the eyes of the law therefore, the people's position is streamlined and central in a democracy.

Nevertheless, the imperative of highlighting the jurisdictional position of both the people and the government, conveys a definite knowledge, purpose and safeguard. This is because, in Pitt's opinion (see Ogbeidi 2012, p.2), "...where laws end, tyranny begins", and the implications of acquiring unlimited power by the Executive are multi-pronged, but collectively gather to the detriment of the people and polity.

A certain period in the history of Nigeria became inauspicious with the trauncating of a democratically established balance. The nuances of that act became an entrenched culture when the military left in 1999 -a culture of impunity and of not playing by the rules. Consequently, a transition occured, in the circumstance, that imminently enthroned personalization of power, resources, and means of political succession. This also saw to the doing away with the 'spirit' while upholding the 'letters' of the social contract since the democratic transition till date. It suffices to submit, that the military heritage of 'rule by fiat' affected the psyche of holders of executive power, who have worked so hard to preclude the people's active participation in government through the Parliament. Certainly ever since, the needs and aspiration of the citizenry are circumvented as the regimes become more manipulative, autocratic, clientelistic, unresponsive and confrontational.

Admittedly, most African states live with this experience. Thus, Maier (2000) recounts that the Nigerian State, which was the focus of great optimism as a powerful emerging nation, that would be a showcase for democratic government, is no exception (see Adebanwi and Obadare 2010, p.380). Successive regimes in Nigeria, over time, both at the centre and in the states, have exihibited greater latitude to circumventing the tenets of the social contract. Thus, the operational distinction provided by the law to govern actions and responsibilities of the different arms of government, and as much the governed, had long been lowered. Personalization of political power and its advantages, and the 'god father' politics in Nigeria, therefore, mirrows the embrace of neo-patrimonialism.

Consequently, in favour of a shift to building patrimonial networks, occupants of political offices are attaching more importance to themselves and their positions than the established rules and responsibilities of their offices and position. Referred to, is the compromised Legislature and Judiciary, and the covetous high-handed Executive. In the words of Bratton and van de Walle (1997, p.269), neo-patrimonialism is an informal political system based on personalized rule and organized through clientelistic networks of patronage, personal loyalty and coercion. This has overwhelmingly become 
the act and state of affairs in the whole of the Nigerian polity. As mentioned in the introductory part of the paper, a template could be drawn using any state in Nigeria. However, Imo state is completely replete with the defining conditions and is therefore a suitable case to portray the depth of the act in Nigeria.

The Weberian conceptual point unfortunately also, toes the path of Hobbes and Rousseau's idea when it described the State (under the Aristocrat), as a human community that claims the monopoly of the legitimate use of physical force in a given territory (Weber 1946). This is potentially a problem source as it defectively reduced the identity of the people, of the popular sovereignty, to a single institutional site - the Executive. Weber's construct is significantly indicted by the trend in Imo politics as illustrated: "In a democracy the people choose a leader in whom they trust. Then the chosen leader says, Now shut up and obey me! People and party are no longer free to interfere in his business" (Gerth and Mills 1991, p.42; Obiyo 2007, p.67). The aspect of sitting in judgement later on, and doing away with him does not hold much promise. This is because the outcome of elections in Imo State are not determined by the verdict of the popular will. Infact, the Imo situation agrees with Iwe's (1984, p.73) opinion, that neither gross ineptitude and incompetence in office nor highly questionable public probity of the incumbent are obstacles to tenure of office, here in Nigeria.

The neo-patrimonial disposition of successive Governors in Imo state and their cronies, would seem to any 'watcher' that such position is their divine inheritance and therefore, exclusively preserved for them. As may be erroneously perceived, the manifestation of patrimonialism in Imo State is not in the form of irregular malpractice, but as a pattern in agreement with the views of Blundo and Olivier de Sardan (2006, p.4), that it is "at the core of relations between public services and their users". It is such that 'any thing goes', and "development is less important to the neo-patrimonial state elites than the continuation of their personal power and prestige" (Gibb 2009, p.716). The situation more or less, is a portrayal of the conversion of the state to a private estate or as simply put by Lindberg (2003, p.123), "privatization of the state", and the hallmark of the dispossession of citizen's political power. This is the effect of the decimation of the principle of checks and balances in Nigeria's political system, and of the Executive having to simultaneously legislate, interprete, and implement its will.

If however, the sovereign status of the state is that of the totality of the individuals who constitute it, then, the legitimacy of any government rests on a claim to represent the desires of its citizens; that is, the claim of government to be doing what the people want it to do (Mallam 2009, quoted in Jamo 2013, p.86). On this premise lies the 'spirit' of the social contract between the government and the people, and would effectively represent the assertion that power belongs to the people, if rigorously observed. Thus, to make progress 
is to see that the formal democratic system and the 'rule of law' gain greater prominence, and eventually, primacy over the 'god father' system and its politics of might (and money) make right (Agbaga et al 2006, p.v).

\section{Leadership and coloniality of power in Imo state}

The state of Imo was created on February 3rd 1976 from the defunct East Central State of Nigeria. It is located in the south-eastern region, and is bordered by Enugu on the North, Rivers State on the South, Abia on the East and on the West, by Anambra State. During the 1991 state creation exercise, parts of Imo was excised to form Abia and Ebonyi States. Imo State lies within latitudes $4^{\circ} 45^{\prime} \mathrm{N}$ and $7^{\circ} 15^{\prime} \mathrm{N}$, and longitude $6^{\circ} 50^{\prime} \mathrm{E}$ and $7^{\circ} 25^{\prime} \mathrm{E}$, with a total area of 5,530 or 5,182.82 square kilometres, and having a total of 27 Local Government Area Councils (LGA) (Ukiwo and Chukwuma 2012, pp.154-155; see also NEWMAP 2011; Imo State Judiciary (n.d.); NigeriaGalleria 2015). These LGAs are mostly supervised by Caretaker Committees, appointed by the Governor, as against the provision of the constitution for an Executive Chairman and Deputy to be elected by the people. In the last 4 years, the Caretaker Committees have been in charge of affairs in all the Local Government Councils.

A descriptive account of the state of leadership and power in Imo State exposes a self-seeking social pattern of interest, structured to control or drive personal goals. It is instructive as the following note rightly emphasizes that:

The problem of Nigeria is simply and squarely a failure of leadership. There is nothing wrong with the Nigerian character. There is nothing wrong with the Nigerian land, climate, water, air or anything else. The Nigerian problem is the unwillingness or inability of its leaders to arise to their responsibility, to the challenge of personal example, which is the hallmark of true leadership. (Chinua Achebe 1984, p.1)

The above proclamation is made relevant by the scramble to put the state and its resources to private use. Succintly put, it affirms as correct, the prevalence of the act of cornering the political economy of the state and undercutting the bonafide owners of the commonwealth -the people of Imo State. This has become possible following the 'compromise' relationship between the three arms of government (the Executive, Legislature and the Judiciary).

Outstanding therefore, is the recognition of what stands as the background of this low state of affairs. This comes in double dimension. Firstly, the impact of foreign conquest and colonization of the Nigerian state. This aspect picks on the colonial forms of authoritarianism underlying the 'indirect rule' system, 
which frustrated the creation of a legitimate social contract among constituent groups -government and the governed (see Agbaga et al, 2006, p.3). In this regard, the introduction of authoritarian culture created a political pattern that encouraged impunity and extra-legal acts by the leadership. Secondly, the incursion into politics by the Military in Nigeria, as previously noted, indeed compounded an already poorly founded system. This exacerbated the autocratic, undemocratic and clientelistic patterns that work against the popular demands and expectations, which democracy offers. Agbaga et al (2006, p.12) support this assertion by their popular remarks that:

Since 1999, Nigeria has not yet transitioned to a legal system or political culture that can be described as fully demcratic. A disconnect between the legal and political process has been a direct consequence of the Military's approach to governance. The result has been citizens being subject to arbitrary government decisions.

The above factors, form the background sketch of what had shaped the political culture, which has taken root in Imo since the return to civil rule in 1999. Currently, there is a level of disorderliness that has affected different strata of public life, for which we see for instance, manipulation of the democratic process, 'do or die' and 'winner takes all' politics etc. All these exist with subsisting instances. On the aspect of elections and patterns of political succession, the position of the people and the popular will is grossly downplayed, given the overriding level of malpractice. In 1999, the candidate of the People's Democratic Party (PDP), Chief Achike Udenwa was declared the winner of the Governorship election in Imo State - an election that was described as flawed and massively rigged nationwide. For instance, the results declared, mostly in the Niger Delta states and in the southeast (mostly PDP stronghold) did not reflect the preferences and will of the people (see Africa Check 2014). Acknowledging the frustration of the monitors and observers of the election, including the former US President, Jimmy Carter, Kew (2010, pp.508-509) observed that:

Although President Carter quite reasonably saw questionable outcomes in roughly two-thirds of the Federation as making the election unacceptable, most of the international community took its cue from Nigerian Civil Society monitors and the public at large, who were willing to live with the outcome in order to get the Military out of power.

After the elections, most of the office holders placed more attention and concentration in building patrimonial networks. This was quite obvious in Imo State as politicians strategized in readiness for the 2003 elections. As against the need to put up observable performance in office, nearly all office holders preoccupied themselves with building up and enjoying the power of incumbency, which the Governors in particular used to their benefit (Kew 
2010, p.509). As such, the 2003 elections went the way of that of 1999. In all, the mandate of 12 years received by the PDP in Imo State yeilded little to nothing, and was of minor impact in the development process of the State. Apparently, political power was not within the range of control by the citizens, and the popular will was far less prevalent.

Following the same patrimonial pattern and elite gang up, a less formidable Ikedi Ohakim/Ada Okwuonu (Progressive People's Alliance) ticket came to power in Imo after the 2007 elections. According to Odife (2012, p.171), this was after the cancellation of the earlier poll result, in which Martin Agbaso of the All Progressive Grand Alliance (APGA) had a comfortable lead in the declared 24 out of 27 Imo Local Government Councils. In his opinion, lack of compromise on working arrangement between Achike Udenwa (the outgoing Governor) and Martin Agbaso, led the former to prevail on the INEC Chairman, Professor Maurice Iwu (who saw it as a win-win situation, to pave the way for his fellow Okigwe man) to cancell the election. Similarly, like his predicessor, Chief Ikedi Ohakim failed to serve the needs and aspiration of Imolites, but followed the path of reckless misappropriation and unnecessary lordliness, reminiscent of the military era.

It is pertinent to note that in all the succession 'horsetrading' and election ruckus since 1999, the will of the people was of no consequence. It did not matter, and ofcourse, never bothered the political 'godfathers', and leaders who had cornered the state funds, and were ready to use it to achieve their preferred ends. Consequently, there was a heated consciousness among the different classes of Imo electorates to reassert their will and make things right again. This unargueably, necessitated the electoral mass revolution witnessed during the 2011 elections. Apparently, Rochas Okorocha who won the election rode on a profound level of disenchantment with the Ohakim administration's failure to give Imo the desired leadership and development (Obi, 2014). Unfortunately still, in more ways than one, Okorocha's administration so far, has also failed Imolites who considered its 'Principal' as the 'messiah' to steer the 'rescue ship' of Imo State to the heights of political and economic development. The rescue drive (Rescue Mission), which was targeted against corruption and weak representation, thus, became not more than a mere semantic showmanship. As it turned out, the captains of the 'rescue mission' became as corrupt and domineering as the previous 'clean and green' government of Godson Ikedi Ohakim.

From the above analysis, it is clear that the required democratic subjectivity to the popular will has been scarcely obtainable in Imo State. While it is properly acknowledged, albeit theoretically, the plurality of institutional representation of the popular will in the current democracy, there seems nothing to celebrate about it in terms of weakness in checks and balances, and of the sovereignty of the popular will. Obi (2016) was on point to have remarked that Imo State has only a "photo Assembly", made up of legislators who never sat, or represented the will of the people, and never held the 
governors to account. The overbearing influence of the Executive in Imo State, has become an inescapable reference to the gradual but steady depreciation of the values of the separation of power principle. Practically, the 'watchdog' institutions (the Legislature and Judiciary) have been silenced to the point that the guarantee of representing and realizing the people's will is no longer sustainable.

Obviously, the dissonant leadership style of the current Imo State Chief Executive is one that disregards and completely eliminates the essence of bureaucracy and 'due process'. The plausibility of this assertion is confirmed in his unilateral decision to sack 10,000 workers duly employed by his predicessor, only to later employ on adhoc basis, from among his supporters, workers not less than 25,000 in number (see Vanguard, January 27, 2016). Similarly, the government has embarked on a 'closed' concessioning spree of its Departments and Parastatals. It is closed in the sense that the normal due process is not followed; the terms of the contract are not clear and beneficiaries are alleged to be government aids and loyalists. Among the agencies so far concessioned in that manner include; the General Hospitals, Imo Water Board, Imo Concorde Hotel, Imo Palm Plantation (Adapalm) and the Imo Transport Company. The process, set to take place in 16 other agencies was bedeveilled by a heated opposition by the Labour Union, about plans to lay off not less than 3,000 workers from these agencies (The Union, January 17, 2016). In all these, the Legislature had no opinion.

The foundation of the writer's arguement therefore, is laid on the understanding that the Executive arm of government can be made accountable to the people, if the Legislature so wants it. However, this is not the case in Imo State. In the opinion of Obi (2015), the Imo Legislature is so subservient to the will and powers of the Executive, and they seem unaware of the fact that whatever power the Governor has, flows from the Assembly, and can be contained by it. In fact, corruption has weakened the supposed institutions of check such that the Legislature for example, no longer 'oversight' the Executive but chase after Contractors. Thus Iwuoha (2015) wrote:

In more ways than one, the Imo Legislature has contributed to the devaluation of leadership and underdevelopment of the State. Otherwise, how can our lawmakers be accepting flight tickets and other pecuniary benefits from the Executive, whom they are expected to put in check? How can our lawmakers be sending list of 'requirements' before 2014 budget can be passed? How can they be colluding to jack up the budget in exchange for road contracts and 'kickbacks'?

In view of these, and other forms of corruption found in the Imo House of Assembly (IHA), she lost all moral grounds to querry the excesses of the Executive. This, therefore, undoubtedly turned her into a lost ball in the weeds, to the 'loss' of the people. The result of these are series of unchallenged actions and decisions by the Executive, that can at best, be described as ultra veris. 
Recently, a process of urban renewal was initiated in Owerri capital city for which demolition of properties was on a massive scale. However, the Governor who took on the demolition of people's properties without the involvement of the Owerri Capital Development Authority (OCDA), didn't also think it was necessary to seek authorization from the IHA. Iwuoha (2016) harped on this, and as much argued that the Governor never sent an executive bill to ask for approval from the IHA to enforce the relocation of 'Eke Ukwu' Owerri market (which is on-going at time of the study), since there is no record of such bill in the 'House'. Expectedly, the compromise and florishing relationship between the Executive and the Legislature, has kept low the democratic temperature of the State, while these anomalies go on. The brunt of the collapse of checks and balances is only borne by the people, who have lost all the means of expression and realization of their collective will.

In the area of infrastruture development, the current government has proved itself as such that churns out substandard projects. Paved roads in the state do not last up to six months before developing potholes. For the government, it is also enough for instance, to have built a hospital, if a building is put up without equipping and bringing it up to service dispensing standard. Over and above the recorded malfeasance of successive governments in Imo State, is their penchant for converting Imo State, its properties and funds into a family enterprise (Uwadi 2011).

Afore illustrations therefore, fit into former President Olusegun Obasanjo's reason for describing some state Governors as emperors, engaged in the business of governing their states not with the overall objective of improving the lives of the citizens (The Guardian, February 2, 2016). However, the opportunity to judge these anormalies, which the electoral process offers, is as earlier highlighted, of no effect, since the possibility of free and fair election is neither here nor there. The credibility of elections is roundly diminished by massive rigging, and the people's votes do not count. Sequel to the outlisted reasons, the people of Imo State did not really have the eagerness to renew Governor Okorocha's mandate in April 2015. Howbeit, like in the usual manner of his predicessors, and "more like a proconsul rather than a servant" (Obi, 2014), he forced himself on the people, and back to 'Douglas House' -the seat of government.

Regrettably, in the search for remedy and justice, the Judiciary was not in the position to help as a result of high level of corruption bedeviling the sector. This trend has continued as the Chief Judge of the State, hand picked by the Governor, is permanently in the Governor's pocket. As such, Imo State can be said to be managed by a government that enjoys no form of public trust. There is a critical question of legitimacy, and "as the democracy crisis deepens, the legitimacy deficit of democratic institutions and elected representatives tends to worsen, resulting in further distancing and alienation 
of the representatives from the electorate"(Amuwo, 2009, p.38). All these however, do not bother the government whose interest is by no means bonded to that of the public.

As regards the hopeless ordinary citizens, a reference to the colonial infusion of the British interest with that of the African aristocrats, paints a picture that agrees with the situation in Imo State. This portrays the action of the British who tried to identify the interests of the (Fulani) elites in Nigeria with its own, such that there was a feeling that any upheaval against the British would equally make an end of them (Lugard 1922, p.195; Adebanwi and Obadare 2010, p.189). This example has become the approach by Imo rulers who recruit hopeless and hapless 'political noisemakers' and jobbers whose interest of getting their own share of the state fund is aligned with those of their benefactors. For this reason and many more, governance has simply become all about reveling in the glory of the offices and the attendant advantages, which it offers to government officials in Imo State (Emecheta 2015, p.10). These 'recruits' work so hard to maintain the clientelage that pays their bills. In this way, citizens are made customers and democracy is demeaned, as they are identified as such (Barrett 2007, p.28). The neo-patrimonial pattern has deeply taken root in Imo State, silenced popular representation and institutions of check, and as Kew (2010, p.513) infers, severing relationship between the rulers and the ruled, and barring accountability such that personal interests become the driving force of politics.

It is necessary however, to bring into context the part played by the 'cooperative population'. This has become important to play down on the populist and accomodative claims of 'prebendalist' governments. The determination and compromise made by some people to redeem their helplessness and pauperization, has for the goverment, become accomodation. This some may argue, is better than intimidation and validates the thoughts of the likes of Joseph $(1987$, p.67) whose opinion is that the appropriation of public offices is not just an act of individual greed or ambition but also the satisfaction of the short-term objectives of a subset of the general population. Incidentally, the government of Imo state combines intimidation with this ascriptive, corrupt, discriminatory, and unjustified form of accomodation.

\section{Dominance through the duality of patronage and force}

A circumspective investigation of the governance process in Imo State reveals an entrenched system of criminal patronage. The type in vogue depicts an idea of the preponderance of affective and ascriptive orientation in the system [this means showing favours to relations and giving out existing opportunities less on merit] (see Emecheta 2013, p.9). A variant of it exists in terms of extending favors and reward to other arms of government by the 
Executive to criminally secure their cooperation and silence. Another is the fact that government by all means, also targets the cooperation and control of the ordinary people. The practice has become endemic in Nigeria, ditto Imo State, where every political favor is linked to one form of relationship or the other (see Imo Trumpeta July 12, 2012). On the other hand, an alternative indulgence regardless of whether there exist a relationship or not, has been to create new ones and to garner fresh loyalty. Thus, predication is upon enlarging the coast of existing patrimonial network.

A telling illustration, locates this practice as cutting across all strata of government arms and establishments in Imo State (dubbed the Eastern Heartland). In the state Judiciary for example, employment has over the years been predominantly, based on patronage as against merit. Almost every employee has link or came into service allegedly through one Judge or the other, or through a member of the Board of the Judicial Service Commission, etc. In this circumstance, employee conduct, performance and loyalty is also determined by this reality. This explains the frigidity of character and conduct observed in the Service, and ofcourse the quality of service delivery. In their paper titled, 'Replacing Political Patronage with Merit: The Roles of the President and the Congress in the Origins of the Federal Civil Service System', Johnson and Libecap (1994) traced the use of patronage in the make up of the ninteen century United States federal labour force. They observed that patronage at the time was the currency of political exchange (p.12). However, this had to change because, “...civic-minded reformers objected to the inefficiencies and corruption, alleged to be inherent in a system of patronage, and they worked to deny the reelection of members of Congress who were supporters of the spoils system and to replace them with members sympathetic to reform" (Ibid, p.13). In these scenarios, government officials appropriated the patronage system to favor their political escapades, while citizens watch helplessly, as this trends.

In a situation where the concept of 'separation of power' is no longer sustained in Imo State, the Governor, being the chief executive, controls all because he controls the allocation of funds and values. In different ways and means, he controls the other arms of government, and ofcourse the popular will within and without the plurality of institutional sites and representation in the state. Consequently, the exercise of political power and mandate in the State remains within the purview of the description tendered by Jackson and Rosberg (1982, p.19) as "a system of relations linking rulers not with the 'public' or even the ruled (at least not directly), but with patrons, associates, clients, supporters, and rivals, who constitute the "system"'. By all standards therefore, the patron-client system has become formidable, and a tool of note for political manipulation, dominance and (mis)appropriation of the powers allotted to the people by the law. 
Similarly, the level of impunity by government officials, at times, get to the point of using intimidation and force to achieve cooperation and compliance, especially as regards to regime's stability and tenure. Ochonu (2004) wrote that "these political office holders hire thugs and state security agents and intimidate opponents and dissenting members of the public" (see Ugiagbe and Omigie 2014, p.251), in a brazen personalization and abuse of power. Most of the politically motivated killings and kidnapping in the state are attributable to intolerance to opposition and the desire to dominate. Some graphical examples include;

-On February 8, 2003, Mr. Ogbonnaya Uche, a chieftain of the All Nigerian People's Party (ANPP) and a senatorial aspirant in the Orlu senatorial zone, Imo State was shot in his residence not long after he defected from the People's Democratic Party to ANPP.

-On February 22, 2003, Mr. Theodore Agwatu, Principal Secretary to the Governor of Imo State, was murdered by suspected hired assassins in Owerri.

-On April 19, 2003, Toni Dimegwu, an ANPP member of the House of Assembly was killed in Imo State.

-On April 20, 2003, Onyewuchi Iwuchukwu, a stalwart of the ANPP, was murdered in Ikeduru Local Council, Imo State.

-In March 2004, Mr. Uche Ogbe, the Chairman, College of Education Academic Staff Union, Alvan Ikoku College of Education was murdered in Owerri.

-In January 2013, Laz Anyanwu, the Imo Deputy Governor's Director of Protocol, was murdered and the body mutilated by Gunmen.

-On February 4, 2014, Noel Tochukwu, a USA based Showbiz promoter was murdered in an Owerri-based Hotel.

-In September 2014, Aduba, an aid to the Speaker of Imo House of Assembly was killed over an alleged tussle for position and power.

-In January 2015, Mr. Tobias Onyekele, a serving Commissioner in the Imo State House of Assembly Service Commission was killed in the midst of rising political tension.

On April 3, 2015, Mr. Andrew Ugwuezumba, the Labour Party House of Assembly candidate was killed at Ngor Okpala, Imo State.

-There are a number of politically motivated kidnappings in Imo State, including the abduction of Dr. Vincent Udokwu, the former Chief of Staff in Achike Udenwa's government, and Barrister Godfrey Dikeocha, former Speaker of Imo State House of Assembly. These were done primarily to cut down their influence in the electoral process, in favour of the opponents.

Source: Imo Trumpeta <www.imotrumpeta.com/?p=11342>, and Author's personal observation and compilation. 
While the list is inexhaustive, it depicts a climate of insecurity and absence of freedom of the popular will. It is commonplace that people are coersed to make electoral choices that are at variance with their wishes and aspiration. This again, gives credence to Ugiagbe and Omigie's (2014, p.250) opinion that, "Nigeria's political leaders especially state governors, have been employing the carrot and the stick in a strategic exercise of power". As a result, if one yields an opposing view to the standpoint of the government, he is labelled an enemy of the state and therefore, would not expect to have his peace. In this scenario, a befitting interpretation is that the people are cowed to submission via threats, not only to their lives and existence, but also to their welfare and future.

\section{Implication to service delivery}

In their study of the effects of corruption to service delivery in the Nigerian Public Service, Kayode et al (2013) applied the 'Principal-Agent Model' of analysis to portray the abuse of existing privileges by public servants (Agents), to the detriment of the citizenry (Principals). In the course of their inquiry, concerns were raised among other things, about the overarching self-interest of government officials, and how such could be 'burdened' and 'softened' to upgrade and broaden the course of service delivery (Ibid, p.003; see also Batley 2004). A recourse to discussions made so far in this paper, also shows that the whole scenerio is replete with accounts of self-serving, clientelistic mode of governance in Nigeria. Indeed, the implication of this to the quality and quantity of service delivery is obvious. Infact, for want of legitimacy, clientalistic regimes appropriate state funds in such a manner that diminish their developmental capacity. Clearly, the established conduct of political office holders and public officials in Nigeria, as reviewed, is antithetical to the demands of good governance by the citizens, sequel to which if one abounds, the other retrogresses. The retrogression is evident in the complete erosion of citizen's democratic rights, privileges and powers. By this therefore, the people lack the clout to fight the ills of government.

In Imo State, corruption, high-handedness and non submission to popular will are identified as whole factors, consisting of other subordinates that predominate and exert weight against service delivery. The flourishing impunity, resource looting, electoral malpractices, disregard to 'rule of law' and 'due process' etc, beget equal account of disappointment, misery, poor social facilities and dysfunctional infrastructure, conflict and instability etc. By these, the state of service delivery in Imo is highly affected, poor and alarming. Human security, interpreted as protection from the threat of disease, hunger, unemployment, crime, social conflict, political repression, and environmental 
harzards (UNDP 1994, p.22), has been a matter of no concern to successive governments in the State. The socio-economic life of the people is like-wise, at the lowest ebb.

The purported flagship projects of the current government in Imo State, mostly carried out during the regime's first tenure, are mere landmarks that have no bearing on the economy and welfare of Imolites. Perhaps, their choice conform to Mauro's (1997, p.7; see also Emecheta 2015, p.11) views that "corruption tempts government officials to choose government expenditures less on the basis of public welfare than on the opportunity they provide for extorting bribes". Today, the act of treasury looting and clientelism, have foreclosed further project execution in the State. While the partial free education scheme in the State provides some sort of reprieve, there is no hope in the health system. Hospitals are poorly equipped and staffed, and are without drugs for treatment of patients. The story is the same, in the areas of provision of affordable means of transportation and housing, even as the tenancy rate in the state is comparably high.

Similarly, government of the State pays lip service to social protection options and pro-poor empowerment measures. Whereas budgetary allocations are made to attend to these areas of need, at the end of the day, such are diverted to other uses. The 'Health At Your Door Step' programme of Okorocha's government is a clear example of a service paid or budgeted for, but not delivered to the citizens. In general terms therefore, it would be safe to say that the self-seeking and patrimonial pattern of leadership in Imo State, engendered by the absence of appropriate checks and balances, and loss of political power by the people, has made negative impact on service delivery. Such areas as economic, security, health, social protection, and most of all, owing of arrears of pension to vulnerable retirees, are particularly listed as most affected. This is primarily because successive governments in the state, following this pattern, have not considered service delivery as the raison d'etre of their mandate and service. Consequently, the desired spade work necessary to provide efficient health service, quality education, employment, security and other forms of social service, is roundly evaded.

\section{The way forward}

The brand of democracy we copied from the developed world and pretend to be practicing, has been so perverted in our hands. What would possibly be the content and character of a democracy where the people and the law are no longer of reference and value? A huge leeway has been created in the circumstance, giving the privileged few in leadership positions, the leverage to plunder the system. However, the unacceptibility of this trend is being 
demonstrated in diverse fashions. Outside the shores of Nigeria, the 'Arab Spring' notably represents a disapproval by the people, of lordliness and misapplication of power by the leadership of the affected countries. Similarly, we have in Nigeria, the harrowing experience of the Niger Delta uprising and the Boko Haram debacle. Against the popular branding of the cause of the Boko Haram episode as religious, rigorous investigation overtime, proves the cause factor as primarily socio-economic and to an extent political. Indeed, in different ways, statements have been made as to how the people feel about their state of alienation, impoverishment and acts of dispossession of their legal rights and dignity.

As observed earlier, and in a bid to reclaim their social, economic and political rights, Imo citizens in 2011 rose up to the occasion. They sought to do this peacefully through the ballot as noted, but that did not produce any current hot enough to create a scare on the tough skin of Imo politicians. While discriptive points have been made to show serial violation of the democratic principles; the 'rule of law', popular sovereinty, governance for the security and welfare of the people, etc, there seems to be no end to it without a committed campaign. However, hard issues deserve hard measures to tackle. Therefore to avoid the 'hard way becoming the only way', it means 'soft measures' must of need be urgently taken, and that, in the views of the author, include the application of the following recommendations;

a. There is the need to go back to the drawing board to properly sketch and build our democracy around the people and the law. A redefinition of the practice will only include that process that would entrench 'due process' and put the people at the centre of political decisions and authority. We must see in reality, power belonging to the people, and government being chosen freely by the people, working for the good of the people. Again, in Nigeria and particularly in Imo State, effort must be concentrated at building strong institutions as against strong individuals. In all, let the law be preeminent, and rule over all.

b. The virtues of the 'rule of law' must be harnessed to restore the autonomy of the three arms of government and to create a healthy mode of cooperation, and appropriate 'checks and balances' among them. In the spirit of 'separation of power', non should be too powerful to intimidate or control the other. It is also necessary to strenghten the process of 'recall' of irresponsible and unresponsive representatives of the people.

c. Cases of corruption and high-handedness must not be treated loosely, and all aspects of relevant laws must be strenghtened to deal with such cases. To that extent, the practice of 'plea bargaining' in Nigeria must be viewed as abominable. It is to say the least, an act of providing 'soft landing' for criminals and enemies of the state, which must be avoided. 
d. The government of Nigeria and that of the states must braceup to the task of re-building people's confidence in government and governance. People's welfare must be prioritized, and all action seen to be for the common good of all. Building on this principle produces a compelling urge to give more attention to human resource development among other considerations.

e. Other areas to put the spanner on, are in the issues of electoral malpractices and violence, and conducting of free, fair and credible elections; the winner takes all syndrom; lack of internal democracy among the political parties, etc. The need for active Civil Society Organizations in advocacy cannot be overemphasized, including the need for a viable opposition to checkmate the dwindling social contract.

All recommendations are anchored on the imperative to enhance democratic consolidation and to reassert the principle of the social contract between the government and the people.

\section{References}

Achebe, C., 1984. The Trouble With Nigeria. Oxford: Heinemann Educational Publishers.

Adebanwi, W. and Obadare, E., 2010. Introducing Nigeria at fifty: the nation in narration. Journal of Contemporary African Studies, 28(4), pp. 379-405.

Africa Check. 2014. Is the Niger Delta region the 'epicentre of electoral fraud' in Nigeria? Available at: $<$ https://africacheck.org/reports/is-the-delta-the-epicentreof-electoral-fraud-in-nigeria-2/> [Accessed: September 10, 2016].

Agbaga, A. et al., 2006. Democracy and Governance Assessment of Nigeria, Vermont: ARD/USAID.

Amuwo, A., 2009. The Political Economy of Nigeria's Post Military Elections, 19992007. Review of African Political Economy, 36(119), pp. 37-61.

Appadorai, A., 1975. The Substance of Politics. Madras: Oxford University Press.

Barrett, J., 2007. Distant greener grass? Lessons for South Africa from New Zealand's experience of new public management. POLITEIA: South African Journal of Political Science and Public Administration. 26(1), pp. 18-32.

Batlay, R., 2004. The Politics of Service Delivery Reform. Institute of Social Studies United Kingdom: Blackwell Publishing.

Blundo, G. and Olivier de Sardan J. P., 2006. Everyday corruption and the state: Citizens and Public Officials in Africa. London: Zed.

Bratton, M. and Van de Walle N., 1997. Democratic Experience in Africa: Regime Transitions in a Comparative Perspective. Cambridge: Cambridge University Press. 
Emecheta, K. O., 2015. Investigating the causal factors of low development in the Lake Chad Basin. Afro-Asian Journal of Social Sciences, 6(3), Quarter iii. Pp. 1-21.

Emecheta, K. O., 2013. Fostering stability and development in Nigeria through integrated youth and gender empowerment process and planning. Afro-Asian Journal of Social Sciences, 4(4.4), Quarter iv. Pp. 1-19.

Federal Republic of Nigeria. 1999. Constitution of the Federal Republic of Nigeria, 1999, Abuja: Government Printers.

Gerth, H. and Mills C., 1991. From Max Weber: Essays in Sociology, London: Routledge.

Gibb, R., 2009. Regional integration and Africa's development trajectory: metatheories, expectations and reality. Third World Quarterly, 30(4), pp. 701-721.

Hobbes, T. 1976. The Leviathan. London: J.M. Dent.

Imo State Judiciary (n.d.) The establishment/origin of the Imo State Judiciary System. Available at: <www.imojudiciary.gov.ng/docs/history_file.htm> [Accessed: September 21, 2016].

Iwe, N. S. S., 1984. The reality of the Nigerian social scene- selfishness, AMAN: Journal of Society, Culture and Environment, 3(2), pp. 71-80.

Iwuoha, I. S., 2016. Okorocha, Demolition of Properties and Relocation of Ekeukwu Owerri Market. Imo Trumpeta, Vol. 6, No. 28, July 19.

Iwuoha, I. S., 2016. How Imo State is underdeveloped: The Legislative perspective. $<$ m.thenigerianvoice.com/sports/181009/2/how-imo-state-is-underdevelopedthe-legislative-p.html $>$ [Accessed: July 19, 2016].

Jackson, R. H. and Rosberg, C. G., 1982. Personal rule in black Africa. Berkeley: University of Califonia Press.

Jamo, I. A., 2013. Democracy and Development in Nigeria: Is there a link? Arabian Journal of Business and Management Review (OMAN Chapter), 3(3), pp. 85-94.

Johnson, R. N. and Libecap G. D., 1994. Replacing Political Patronage with Merit: The Role of the President and the Congress in the Origins of the Federal Civil Service System. In: Johnson, R. N. and Libecap, G. D. (eds.), The Federal Civil Service System and the Problem of Bureaucracy, Chicago: University of Chicago Press.

Joseph, R. A., 1987. Democracy and prebendal politics in Nigeria- The rise and fall of the Second Republic. Cambridge: Cambridge University Press.

Kayode, A., Adagba S. and Anyio S. F., 2013. Corruption and service delivery: the case of Nigerian public service, Wudpecker Journal of Public Administration, 1(1), pp. 001-006.

Kew, D., 2010. Nigerian elections and the neopatrimonial paradox: in search of the social contract. Journal of Contemporary African Studies, 28(4), pp. 499-521.

Lindberg, S. I., 2003. It's our time to 'chop': Do elections in Africa feed neopatrimonialism rather than counteract it? Democratization, 10(2), pp. 121-140. 
Lutz, D.S., 1980. Popular consent and popular control: Whig Political Theory in the Early State Constitution. Louisiana: Louisiana State University Press.

Maier, K., 2000. This house has fallen: Nigeria in crisis. Boulder, CO: Westview.

Mallam, B., 2009. National security as a tool for sustainable development in Nigeria: an assessment of Nigerian Police Force. Paper presented at the National Conference on security and Nigeria's quest for development organized by the Kaduna State University.

Mauro, P., 1997. Why worry about corruption? IMF Economic Issue 6, Washington, D.C: IMF.

Obi, N., 2014. Rochas Okorocha and his Vuvuzela administration in Imo. Vanguard News, January 5th. Available at: <http:/www.vanguardngr.com/2014/01/rochasokorocha-vuvuzela-administration-imo/> [Accessed: December 13, 2015].

Obi, N., 2015. Okorocha's Lackeys. Vanguard News, September 20th. Available at: $<$ http://www.vanguardngr.com/2015/09/okorochas-lackeys/> [Accessed: July 19, 2016].

Obi, N., 2016. Rochas Okorocha's endgame in Imo State. Vanguard News, August 7th, <http://www.vanguardngr.com/2016/08/rochas-okorochas-endgame-in-imostate/> [Accessed: September 10, 2016].

Obiyo, R., 2007. Democracy and the Committee System of the South African Parliament with special reference to the Standing Committee on Public Accounts. POLITEIA: South African Journal of Political Science and Public Administration. 26(1), pp. 60-79.

Odife, I., 2012. The April/May 2011 Gubernatorial Poll in Imo State: A triumph of the Masses. Unizik Journal of Arts and Humanities, 13(1), pp. 160-183.

Ogbeidi, M. M., 2012. Political leadership and corruption in Nigeria since 1960: A socio-economic analysis. Journal of Nigeria Studies, 1(2), pp. 1-25.

Rawls, J. 1999. A theory of justice. Cambridge, MA: Belknap Press.

Rousseau, J. J., 1968. The social contract. London: Penguin Group.

Stiglitz, J., 2004. The roaring nineties: Why we're paying the price for the greediest decade in history, London: Penguin Books.

The Guardian. 2016. Governors have become emperors, says Obasanjo. Vol. 32, No. 13,549, Tuesday, February 2, 2016.

The Union. 2016. Again, Governor Okorocha sacks 7000 workers ...insists measure meant to make Imo better. January 17. <theunion.com.ng/news/again-govokorocha-sacks-7000-workers-insists-measure-meant-to-make-imo-better/> [Accessed: September 8, 2016].

Ugiagbe, E. O. and Omigie, O. S., 2014. Power to the people or power in the people, reflections on the Nigerian democratic system: Implication for policy development. Academic Journal of Interdisciplinary Studies, 3(4), pp. 247-252.

Ukiwo, U. and Chukwuma, I., 2012. Governance and insecurity in southeast Nigeria. Lagos: Cleen Foundation. Available at: <cleen.org/books.html> [Accessed: September 21, 2016]. 
United Nations Development Programme (UNDP), 1994. Human Development Report. $<$ http://hdr.undp.org/report/global/1994/en/> [Accessed: Februay 3, 2016].

Uwadi, K., 2011. The sale of Imo State owned Adapalm to Roche Group. The Moment Newspaper, November 7 th.

Vanguard News. 2015. Exploring the resource control option-Imo State by Futureview CEO, Elizabeth Ebi. <http://www.vanguardngr.com/2015/06/exploring-theresource-control-option-imo-state-by-futureview-ceo-elizabeth-ebi/> [Accessed: February 2, 2016].

Vanguard News. 2016. Sacking of Imo Workers: Okorocha on slopes of failure. January 27. <www.vanguardngr.com/2016/01/sacking-of-imo-workers-okorochaon-slopes-of-failure $>$ [Accessed: September 8, 2016].

Weber, M., (1946) 1967. Politics as a vocation. In From Max Weber: Essays in Sociology, edited by H.H. Gerth and C.W. Mills, 77-128. New York: Oxford University Press.

\section{Notes}

1. The patron-client concept was used interchangeably with patrimonialism, neopatrimonialism and clientelism. They all give expression to the reduction of citizens to the status of customers to the people in government.

2. The information cited from the Vanguard News of June 2, 2015 could be accessed at the following web address <http://www.ngex.com/nigeria/places/states/imo.htm>.

3. Prebendalist government and governance, as applied in the sub-theme "leadership and coloniality of power in Imo State", denotes the use of public resources by government officials for their own benefit and that of their cronies. It explains the patron-client practice and identity politics, which has become the norm in Nigeria.

\section{About Author}

\section{Kingsley ONYEMEKARA EMECHETA}

He is Research Fellow in French Institute for Research in Africa (IFRA-NIGERIA), Ibadan, Nigeria. Author has contributed to a number of referred Journals, co-contributed a book chapter, and delivered conference papers. 